\title{
Record of a NeONate DWARf SPERM WHALE, Kogia SIMA (OWEn, 1866) STRANDED ON THE COAST OF BAHIA, NORTHEASTERN BRAZIL ${ }^{1}$
}

\author{
Luciano Raimundo Alardo Souto $2,3,{ }^{*}$, Luana Muritiba Lemos ${ }^{3}$, \\ Thais Helena A. S. Violante ${ }^{2}$, and Rodrigo Maia-Nogueira ${ }^{2,3}$
}

On 9 February 2005, at around 11:00h, a male neonate Kogia sima was rescued on Itapuã beach (12 $57^{\prime} 22^{\prime \prime} S$, $38^{\circ} 21^{\prime} 30^{\prime \prime} \mathrm{W}$ ), Salvador, Bahia, and the CRMA (Centro de Resgate de Mamíferos Aquáticos) network was informed. According to witnesses, the neonate was found alive but injured on the rocks. At the time of collection, the animal had already died. The carcass was in a code 2 condition (Geraci and Lounsbury, 1993) and was not bloated (Figure 1a). The teeth were unerupted and the throat grooves were absent, a fact probably related to its young age. It had various external scratches and was missing a relatively small portion $(\sim 5 \%)$ of its epidermis due to trauma from shocks against reef rocks (Figure $1 b$ ). The animal measured $72.5 \mathrm{~cm}$ in total length from tip of snout to tail notch [using a tape measure of $0.5 \mathrm{~cm}$ precision; morphometrics adapted from Norris (1961)] and had a body mass of $10 \mathrm{~kg}$ (measured with a balance scale of $100 \mathrm{~g}$ precision). Evidence of recent scarring of the navel, as well as the presence of milk in the stomach (identified by its greasy consistency and viscosity) indicated that the animal was lactating. All materials collected were deposited in the Scientific Collection of the Instituto Mamíferos Aquáticos, under classification number CCPM0209.

Considering the known range in total length for newborn K. sima $(100-130 \mathrm{~cm})$ and comparing the case reported here with reported values for total body length (mean $95.4 \mathrm{~cm}$, maximum-minimum values $72.5-112.5 \mathrm{~cm}$ and $\mathrm{sd} 14.08 \mathrm{~cm}$ ) (Kami and Lujan, 1976; Ross, 1979; Caldwell and Cadwell, 1989; Debrot and Barros, 1992; Hetzel and Lodi, 1993; Jefferson et al., 1993; Brito, 19964; Soto and Ternes-da-Silva, 19985; Marcondes et al., 20026; Shirihai and Jarrett, 2006), it is evident that the specimen reported here $(72.5 \mathrm{~cm})$ was much smaller. While we do not discount that this individual may have been an outlier, we suggest that the range be lowered to $72.5-130 \mathrm{~cm}$. Little is known about the biology of K. sima in Brazilian waters, and globally the species is classified as 'Data Deficient' (IUCN, 20107).
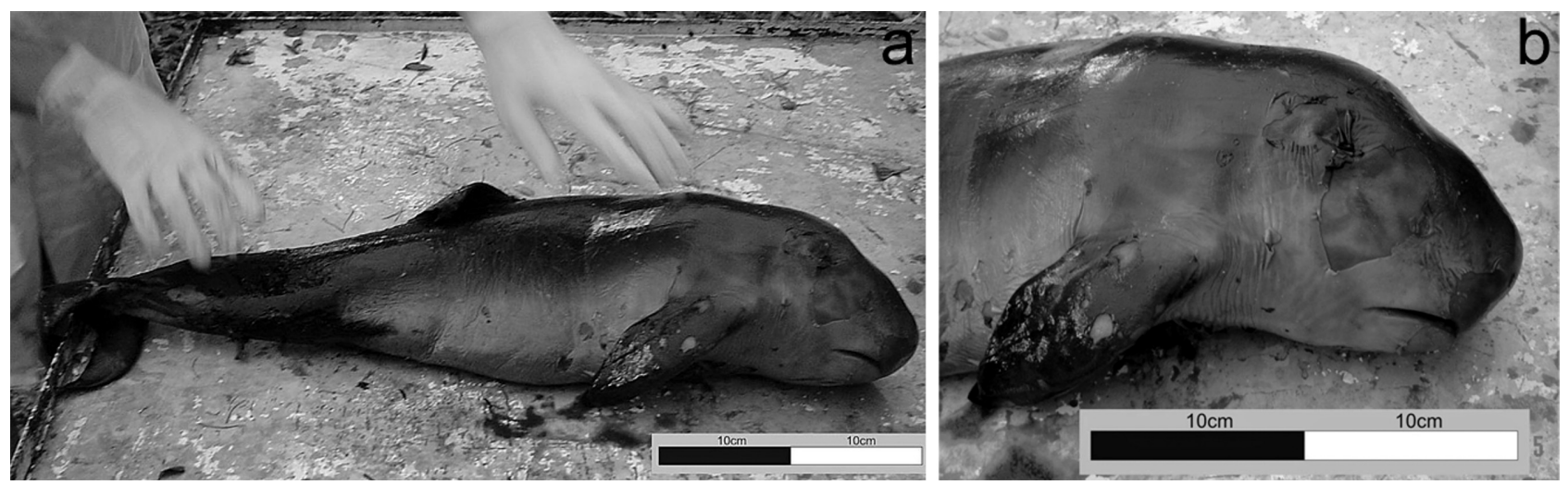

Figure 1. Neonate male dwarf sperm whale, Kogia sima, stranded at Itapuã beach, Salvador, Bahia (CCPM0209). (a) Lateral full body view. (b) Lateral head view.

\footnotetext{
${ }^{1}$ Received on 11 October 2008. Accepted on 1 December 2009. Managed by Nélio Barros / Karina Acevedo-Whitehouse.

2 Setor de Curadoria, Centro de Resgate de Mamíferos Aquáticos (CRMA), Instituto Mamíferos Aquáticos (IMA). Av. Pinto de Aguiar, rua dos Radioamadores, $n^{\circ} 73$, Pituaçu, 41741080, Salvador, BA, Brasil.

${ }^{3}$ Universidade Católica do Salvador (UCSal). Av. Pinto de Aguiar, n 2.589, Pituaçu, 41740090, Salvador, BA, Brasil.

* Corresponding author, e-mail: lucianoalardo@yahoo.com.br.

${ }^{4}$ BRITO, J.L. (1996) Segundo registro de Kogia simus para la costa de Chile. Page 82 in Anais da $7^{\circ}$ Reunión de Trabajo de Especialistas em Mamíferos Acuáticos de América del Sur e $1^{\circ}$ Congreso de la Sociedad Latinoamericana de Especialistas en Mamíferos Acuáticos, Viña Del Mar, Chile, 22-25 October 1996.

${ }^{5}$ SOTO, J.M.R. and TERNES-SILVA, S. (1998) Novos registros de Kogia breviceps e Kogia simus (Cetacea, Physeteridae, kogiinae) no sul do Brasil e revisão dos registros em águas Brazileiras. Page 270-272 in Resumos XI Semana Nacional de Oceanografia, Fundação Universidade do Rio Grande, Rio Grande.

${ }^{6}$ MARCONDES, M.C.C.; LUNA, F.O.; LIMA, R.P. (2002) Rescue and care of a neonate dwarf sperm whale (Kogia simus) predated by a cookiecutter shark (Isistius Braziliensis). In Abstracts Proceedings of the Florida Marine Mammal Health Conference, Gainesville, Florida. U.S.A.

${ }^{7}$ IUCN (2010) IUCN Red List of Threatened Species. Version 2010.1. Available online at <www.iucnredlist.org>. Consulted on 1 May 2010.
} 
It is clear that further information is needed on the biology and reproductive parameters of $K$. sima in this region.

\section{Acknowledgements}

To the Police Environmental Protection Division (COPPA), which helped with the rescue and transport of the animal; the fishing community of Itapuã beach, who reported the stranded animal and removed it from the water; to Liliane Lodi, Nélio B. Barros and Salvatore Siciliano for providing references; graphics support to Paulo Alves for the artwork in Figure 1, to Lauren Hopkins and Vanessa D'Oliveira for their translation of our manuscript and especially to Liliane Lodi, Cláudio L. S. Sampaio, Gerson de O. Norberto, José de Anchieta Nunes, Maria do Socorro S. dos Reis and two anonymous referees for their valuable suggestions on the manuscript.

\section{References}

Caldwell, D.K. and CAldwell, M.C. 1989. Pygmy Sperm Whale Kogia breviceps (de Blainville, 1838): Dwarf Sperm Whale Kogia simus Owen, 1866. Pages 4:235-260 in Ridgeway, S.H. and Harrison, R. (Eds): Handbook of Marine Mammals, Academic Press, London.
Debrot, A.O. and Barros, N.B. (1992) Notes on a Gervais' beaked whale, Mesoplodon europaeus, and a dwarf sperm whale, Kogia simus, stranded in Curaçao, Netherlands Antilles. Marine Mammals Science 8: 172-178.

Geraci, J.R. and Lounsbury, V. (1993) Marine Mammals Ashore: a field guide for strandings. Texas: Texas A\&M Sea Grant Publications.

Hetzel, B. and Lodi, L. (1993) Baleias, Botos e Golfinhos: Guía de Identificação para o Brazil. Editora Nova Fronteira, Rio de Janeiro.

JefFerson, T.A.; LeatherWOOd, S.; WebBer, M.A. (1993) Marine Mammals of the World: FAO Species Identification Guide. UNEP/ $\mathrm{FAO}$, Rome.

Kami, H.T. and Lujan, R.J. (1976) Records of the Dwarf Sperm Whale Kogia simus Owen from Guam. Micronesica 12(2): 327-332.

NorRIS, K.S. (1961) Standardized methods for measuring and recording data on the smaller cetaceans. Journal of Mammalogy 42(4): 471-476

Ross, G.J.B. (1979) Records of pygmy and dwarf sperm whales, genus Kogia, from southern Africa, with biological notes and some comparisons. Annals of the Cape Provincial Museums (Natural History Series) 11 (14): 259-327.

ShirihaI, H. and JarretT, B. (2006) Whales, Dolphins, and other Marine Mammals of the World. New Jersey, Ed. Princeton University Press. 